\title{
GLIS2 wt Allele
}

National Cancer Institute

\section{Source}

National Cancer Institute. GLIS2 wt Allele. NCI Thesaurus. Code C105901.

Human GLIS2 wild-type allele is located in the vicinity of $16 \mathrm{p} 13.3$ and is approximately 25 kb in length. This allele, which encodes zinc finger protein GLIS2, plays a role in the modulation of both signaling and transcription. Mutation of the gene is associated with type 7 nephronophthisis. 